\title{
Advances in Thrombolytic Therapy for Acute Myocardial Infarction
}

\author{
Eric J. Topol, MD
}

\begin{abstract}
There has been rapid proliferation of understanding and experience with thrombolytic therapy for acute myocardial infarction. Over the last few years, selective intracoronary infusion of lytic therapy has been replaced by intravenous administration because of the fundamental importance of time to reperfusion. Newer thrombolytic agents, such as tissue plasminogen activator (t-PA) and acylated streptokinase (APSAC), with properties distinct from streptokinase (SK) and urokinase, have been developed and have undergone extensive clinical trial evaluation. This review will focus primarily on the recent advances in thrombolytic therapy, with particular attention to efficacy, safety, and comparative aspects of the various agents currently or soon to be available.
\end{abstract}

\begin{abstract}
Gince the initial work with streptokinase (SK) $\mathcal{~ m o r e ~ t h a n ~} 40$ years ago by Tillett, Sherry, and colleagues, ${ }^{1.2}$ there have been prodigious advances in the application of this form of therapy to patients. The major clinical focus of thrombolytic therapy has been acute myocardial infarction because of its high incidence, relatively small burden of fresh.(minutes to hours) thrombus, ease of demonstrating clot dissolution, and fatal potential. Paralleling the development of fibrinolytic agents, several milestones in diagnosing and treating the patient with acute myocardial infarction have promoted the current rapid growth phase of clinical investigation. In chronologic order these include the postulate by Herrick in 1912 that coronary thrombosis was the inciting event of myocardial infarction, ${ }^{3}$ direct infusion of SK into the infarct-related artery by Chazov and later Rentrop in the mid- and late $1970 \mathrm{~s},{ }^{4.5}$ and the angiographic demonstration of total occlusion of the coronary artery in nearly $90 \%$ of patients with fewer than 4 hours of symptoms by DeWood, with confirmation of thrombus at early coronary bypass surgery. ${ }^{6}$ The large experience of DeWood and colleagues also served to demonstrate the safety of immediate coronary angiography and thus permitted the wide use of this procedure in the early hours of evolving myocardial infarction.
\end{abstract}

From The Division of Cardiology, Department of Internal Medicine, University of Michigan Medical Center, Ann Arbor, Michigan. Address for reprints: Eric J. Topol, MD, Associate Professor, B1-F245 University of Michigan Hospital, 1500 E. Medical Center Drive, Ann Arbor, MI 48109-0022.

\section{THE FULL CIRCLE: INTRAVENOUS TO INTRACORONARY TO INTRAVENOUS THROMBOLYTIC THERAPY}

The earliest application of thrombolytic therapy for acute myocardial infarction involved intravenously administered streptokinase (SK). ${ }^{7}$ However, early clinical trials that used intravenous SK or urokinase did not show efficacy in terms of mortality reduction. ${ }^{8.9}$ The disparity between previous findings and the current experience relates to the relatively late (up to 24 hours) administration and considerably lower doses of the fibrinolytic enzymes. Despite these shortcomings, pooled analysis of the intravenous studies of SK suggested a significant $20 \%$ reduction in mortality compared with placebo or conventional therapy. ${ }^{10}$

Intracoronary fibrinolytic therapy became popular in the early 1980s after Rentrop, Ganz, and others demonstrated the high efficacy of selective SK infusion for reperfusion of the occluded coronary artery. ${ }^{11.12}$ In a major precedent for regulatory issues, (discussed subsequently) in 1982 the United States Food and Drug Administration (FDA) approved the use of intracoronary SK for acute myocardial infarction. The approval (and subsequent approval for urokinase) was based on the ability of intracoronary SK to restore patency of the occluded coronary artery without any data available at that time on ventricular function or mortality.

Two major randomized studies of intracoronary SK subsequently demonstrated salutary effects beyond the demonstration of reperfusion. ${ }^{13.14}$ The 
TOPOL

TABLE I

Summary of Modern Randomized Intravenous Streptokinase Trials

\begin{tabular}{|c|c|c|c|c|c|}
\hline \multirow{3}{*}{$\begin{array}{l}\text { A. Megatrials } \\
\text { GISSI } \\
\text { ISIS-2 }\end{array}$} & \multirow{3}{*}{$\begin{array}{l}\text { Ref. No. } \\
\qquad \begin{array}{l}35 \\
36\end{array}\end{array}$} & \multirow{3}{*}{$\begin{array}{l}\text { No. Patients } \\
\begin{array}{l}11,806 \\
20,000\end{array}\end{array}$} & \multicolumn{2}{|c|}{ Mortality } & \multirow{3}{*}{$\begin{array}{c}P \\
<.001 \\
<.001 \\
P\end{array}$} \\
\hline & & & \multicolumn{2}{|c|}{$\begin{array}{l}\downarrow 19 \%(50 \% \text { for } \mathrm{Rx} 0-1 \mathrm{hr}) \\
\downarrow 33 \%(0-4 \mathrm{hr})\end{array}$} & \\
\hline & & & LV Function & Mortality & \\
\hline $\begin{array}{l}\text { B. Intermediate trial } \\
\text { ISAM }\end{array}$ & 37 & 1741 & $\uparrow$ & $\downarrow 11 \%$ & NS \\
\hline $\begin{array}{l}\text { C. Smaller trials } \\
\text { Western } \\
\text { Washington } \\
\text { New Zealand }\end{array}$ & $\begin{array}{l}38 \\
39\end{array}$ & $\begin{array}{l}368 \\
175\end{array}$ & $\stackrel{\uparrow}{\uparrow}$ & $\begin{array}{l}\downarrow 35 \% \\
\downarrow 66 \%\end{array}$ & $\begin{array}{l}\text { NS } \\
.04\end{array}$ \\
\hline
\end{tabular}

Western Washington intracoronary SK trial demonstrated a striking $67 \%$ reduction of in-hospital mortality without improvement in ventricular function. ${ }^{13}$ This seemingly paradoxical finding probably resulted from the relatively late time of reperfusion in the trial, with a mean time to SK initiation of 4.6 hours from symptom onset. Other randomized studies of intracoronary SK have similarly been unable to demonstrate improvement of ventricular function when therapy is delayed more than 3 hours from the symptom onset. ${ }^{15-20}$ In contrast, the Dutch Inter-University randomized trial of intracoronary SK, with the adjunctive use of intravenous SK $(43 \%)$ or coronary angioplasty (17\%), showed both augmentation of ventricular function and reduction in mortality. ${ }^{14.21}$ In this trial, patients received intracoronary SK at an earlier time-3.25 hours from the onset of symptoms. A smaller trial by Anderson et al., in which patients were treated relatively early, also demonstrated benefit of ventricular function. ${ }^{22}$

Despite the potential for infarct vessel recanalization, recovery of ventricular function and mortality sparing, intracoronary administration of SK has lost favor. At this point, as far as a primary reperfusion strategy, it can almost be considered defunct. The reasons for the resurgence of interest in intravenous lytic therapy stem from several important considerations. First, intracoronary SK is quite impractical. In 1986 , only a minority (19\%) of U.S. hospitals were equipped with a cardiac catheterization laboratory. ${ }^{23}$ Even in hospitals where cardiac catheterization is available, a 24-hour on-call arrangement is necessary, which is not only expensive but also leads to inherent delays during nonworking hours. It takes approximately 1.5 to 2 hours, on average, to achieve infarct artery recanalization in patients when therapy is primarily dependent on obtaining direct coronary access. Second, for intracoronary streptokinase to be effective, a systemic lytic state is a prerequisite. ${ }^{24.25}$ Thus, the lower doses generally chosen for intracoronary compared with intravenous use do not offer the advantage of a diminished effect on the coagulation system. Third, a recent randomized trial of intracoronary SK versus direct coronary angioplasty demonstrate clear-cut advantages of mechanical therapy, once coronary access has been obtained, with regard to ventricular function and alleviation of the residual stenosis. ${ }^{26}$ Also, several randomized trials of intracoronary versus intravenous SK underscore the advantage of simple, rapid initiation of therapy. ${ }^{27-31}$ Finally, although the recanalization efficacy of intracoronary SK is relatively high (approximately $75 \%$ ), newer, intravenously administered clot-selective agents such as tissue-plasminogen activator ( $t-P A$ ) have achieved similar patency rates. ${ }^{32-34}$ For all these considerations, future use of thrombolytic therapy for myocardial infarction will be by the intravenous rather than the intracoronary route.

\section{MODERN TRIALS OF INTRAVENOUS STREPTOKINASE}

In Table I, the major randomized trials of intravenous SK are summarized. All of these trials have used a 1.5 million unit SK dose given intravenously over 30 to 60 minutes. The two megatrials, GISSI and ISIS-2, collectively account for more than 30,000 
TABLE II

\begin{tabular}{|c|c|c|c|c|c|c|c|}
\hline \multicolumn{8}{|c|}{ Clinical Trials of IV t-PA in AMI Patients } \\
\hline Study & Year & $\begin{array}{c}\text { Type of } \\
\text { t-PA }\end{array}$ & $\begin{array}{l}\text { No. of } \\
\text { Patients }\end{array}$ & Dose & $\begin{array}{c}\text { Efficacy } \\
(\%)\end{array}$ & $\begin{array}{l}\text { Significant } \\
\text { Bleeding } \\
\%\end{array}$ & $\begin{array}{c}\text { Nadir } \\
\text { Fibrinogen } \\
\text { (\% Baseline) }\end{array}$ \\
\hline $\begin{array}{l}\text { Collen et al. }{ }^{32} \\
\text { Williams et al. }^{33} \\
\text { TIMI (phase I) } \\
\text { Verstraete et al. }^{45} \\
\text { Verstraete et al. }^{44} \\
\text { Gold et al. }^{43} \\
\text { Topol et al. }^{34} \\
\text { Topol et al. }\end{array}$ & $\begin{array}{l}1984 \\
1985 \\
1985 \\
1985 \\
1985 \\
1985 \\
1987 \\
1987\end{array}$ & $\begin{array}{l}\text { DC } \\
\text { DC } \\
\text { DC } \\
\text { DC } \\
\text { DC } \\
\text { DC } \\
\text { SC } \\
\text { SC }\end{array}$ & $\begin{array}{r}42 \\
47 \\
143 \\
64 \\
64 \\
29 \\
100 \\
386\end{array}$ & $\begin{array}{l}0.5-0.75 \mathrm{mg} / \mathrm{kg} \\
80 \mathrm{mg} / 3 \mathrm{hr} \\
80 \mathrm{mg} / 3 \mathrm{hr} \\
0.75 \mathrm{mg} / \mathrm{kg} \\
0.75 \mathrm{mg} / \mathrm{kg} \times 1.5 \mathrm{hr} \\
0.4-0.75 \mathrm{mg} / \mathrm{kg} \times 1-2 \mathrm{hr} \\
1.25 \mathrm{mg} / \mathrm{kg} \times 3 \mathrm{hr} \\
1.0 \mathrm{mg} / \mathrm{kg} \times 1 \mathrm{hr} \text { then } 15 \\
\mathrm{mg} / \mathrm{hr} \times 5 \mathrm{hr} \text { (total }=150)\end{array}$ & $\begin{array}{l}72 \\
68 \\
66 \\
70 \\
61 \\
83 \\
84 \\
75\end{array}$ & $\begin{array}{c}9 \\
32 \\
6-10 \\
8 \\
2 \\
\text { NR } \\
23 \\
32\end{array}$ & $\begin{array}{l}92 \\
71 \\
67 \\
76 \\
52 \\
62 \\
65 \\
47\end{array}$ \\
\hline TIMI (phase IE) ${ }^{49}$ & 1986 & SC & 258 & $90 \mathrm{mg} /$ first hr, $60 \mathrm{mg}$ over 4 & $85^{*}$ & NR & NR \\
\hline \multicolumn{8}{|c|}{$\begin{array}{l}\text { Angiography at } 18-48 \mathrm{hr} \text {. } \\
D C=\text { double chain; } N R=\text { not reported; } S C=\text { single chain. } \\
\text { Modified with permission from Collen and Topol: Tissue-type plasminogen }\end{array}$} \\
\hline
\end{tabular}

randomized patients and demonstrate a $20 \%$ and $33 \%$ reduction in mortality, respectively. ${ }^{35.36}$ Only the preliminary results of the placebo-controlled ISIS-2 trial are available thus far. The series consisted of approximately $\mathbf{4 0 0 0}$ patients treated within 4 hours of symptom onset. Smaller trials that have also demonstrated salutary effects of IV SK include ISAM, the Western Washington, and the New Zealand studies. The ISAM trial sample size of 1741 patients was inadequate to detect an effect on mortality, but ventricular function was improved in the subset of patients (55\% of total) who underwent ventricular function study. Also, CK-isoenzyme analysis showed a reduction of infarct size for the patients treated with SK compared with placebo. ${ }^{37}$ The Western Washington trial of $\mathbf{3 6 8}$ patients did not demonstrate significant overall mortality or ventricular function benefit, but subgroup analysis demonstrated that patients with anterior infarction or those receiving SK within 3 hours derived significant recovery of ventricular function. ${ }^{38}$ In contrast, the smaller New Zealand trial demonstrated significant overall beneficial ventricular function and increased survival effects. ${ }^{39}$

These five controlled studies of streptokinase did not incorporate early coronary angiography, so that the direct measure of efficacy-acute infarct vessel recanalization-was not detected. Of course, most of these studies would not have been possible if they required emergency coronary angiography. Other studies in which pretreatment or posttreatment angiography, or both, were performed demonstrated a relatively low, $50 \%$ efficacy for this agent given intravenously. ${ }^{15.40-42}$ This discrepancy between relatively low recanalization efficacy and favorable clinical outcomes has led to the question of the actual mechanism of SK. This is discussed in "Nonthrombolytic and Rheologic Effects" and "Regulatory Issues."

\section{CLINICAL TRIALS OF TISSUE PLASMINOGEN ACTIVATOR}

In contrast to the intravenous SK studies cited above, the experience with t-PA is considerably less in patient numbers but far greater with respect to angiographic characterization. In Table II, the published trials of IV t-PA are summarized. A two-chain preparation of t-PA (Genentech, San Francisco, CA) was used when the first patient received recombinant t-PA in February 1984. By late 1985, six clinical trials had been completed ${ }^{32.33 .43-46}$ with this preparation, and upscaling required a new production method (suspension culture), yielding a predominantly single-chain preparation. The dosing of t-PA is highly dependent on the preparation method, because the single-chain preparation has a $40 \%$ more rapid clearance. ${ }^{34}$ The difference in pharmacokinetics is not actually related to the two-versus 1 chain characteristic but rather to other characteris- 
tics of the production process. ${ }^{47}$ All clinical trials performed since late 1985 have used the suspension-culture preparation. ${ }^{34.48-51}$

Several important results emerged from these t-PA trials. First, the remarkably high and consistent level of infarct vessel patency achieved of 70 to $75 \%$ has been demonstrated with IV t-PA even though the dose and preparation method varied. Second, initial studies suggested that reocclusion may be more problematic with $t-P A,{ }^{33.43}$ but the use of a maintenance infusion (duration of therapy after the first-hour dose) for 3 to 6 hours reduced the rate of reocclusion to less than $12 \%{ }^{43.48}$ The short half-life of the agent ( $<5 \mathrm{~min})$ is particularly advantageous in the clinical setting of acute myocardial infarction. Once thrombolytic therapy has been initiated, the need may arise for emergency coronary bypass surgery or central venous access for temporary ventricular pacing. If significant peri-access or other bleeding occurs, the t-PA infusion can be stopped. Third, some fibrinogen and plasminogen breakdown clearly occurs with t-PA in such a way that this agent has relative but not absolute fibrin selectivity. ${ }^{52-54}$ With the current dosing regimens, the fibrinogen nadir is approximately 30 to $50 \%$ of the baseline value, with only 10 to $12 \%$ exhibiting values of fibrinogen below $100 \mathrm{mg} / \mathrm{dL} .^{53-55}$ Fourth, using pretreatment angiography, the Thrombolysis in Myocardial Infarction (TIMI) investigators demonstrated that a higher dose in the first hour does not increase the 90 -minute patency rate but that it clearly speeds up the recanalization process. ${ }^{51.55}$

\section{OTHER THROMBOLYTIC AGENTS: UROKINASE, APSAC, PROUROKINASE}

Experience with IV urokinase to date has been relatively limited although Mathey demonstrated a $60 \%$ patency rate in a consecutive group of $\mathbf{5 0}$ patients, ${ }^{56}$ and there are ongoing randomized comparative trials with t-PA and streptokinase. Cumulatively, more than 1000 patients have been treated with acylated streptokinase (APSAC), ${ }^{57-63}$ but a recent multicenter randomized-comparative trial with pretreatment angiography demonstrated only a $44 \%$ recanalization frequency with APSAC $30 \mathrm{mg} \mathrm{IV}{ }^{.77}$ Both urokinase and APSAC can be given as a bolus and result in marked fibrinogen breakdown quite similar to that observed with SK. Like SK, APSAC is antigenic and, thus, will provoke a low incidence of allergic reactions $(<5 \%)$ and has limited use for repeat dosing. Urokinase is a direct plasminogen activator without antigenicity or resistance. Prourokinase (scu-PA) is a naturally occurring human enzyme and is the single-chain precursor. To date, there is limited published experience with scu-PA, and no large trials have been completed. The small clinical experience suggests that scu-PA has an adequate $(>50-60 \%)$ infarct vessel patency rate and the agent has a short half-life akin to t-PA. ${ }^{64,65}$

\section{STREPTOKINASE VERSUS TISSUE PLASMINOGEN ACTIVATOR}

To prevent the need for speculation, there have been two multicenter, randomized trials of IV SK compared with t-PA.45.46 The results of these trials and related comparative information are shown in Table III. The TIMI phase 1 trial was devoted to establishing which of the two agents was better. Using a double-blind randomization, the TIMI Study Group showed there was a marked improvement of reperfusion rate with t-PA compared with SK. At seven serial observations during the first 90 minutes after onset of treatment, t-PA resulted in twice the reperfusion rate (90 minutes: $62 \%$ vs $31 \%, P<.001$ ). The striking difference in efficacy is demonstrated in Figure 1 for either infarct vessels with TIMI grade 0 (no perfusion) or those with TIMI grade 1 (penetration without perfusion). These unanticipated, extreme differences in reperfusion frequency between the two agents resulted in premature termination of the trial. ${ }^{46}$

This trial has been criticized for a number of reasons. ${ }^{66.67}$ First, the patients were treated relatively late, at 4.8 hours, related to the requirement for pretreatment angiography. In retrospect, it became clear that SK was highly time dependent for achieving efficacy, so that administration more than 3 to 4 hours from the onset of symptoms resulted in extremely poor thrombolytic efficacy, approaching that seen with spontaneous recanalization. ${ }^{6.41}$ In Figure 2, the results from TIMI graphically show time dependency of SK and lack of this characteristic for $t$-PA. However, superior thrombolytic efficacy was evident for $t-P A$ versus SK even when the agents were administered fewer than 4 hours from symptom onset. Although a minority of patients (101 of 290 , or $35 \%$ ) treated in this trial were less than 4 hours from symptom onset, data from the European Cooperative trial, in which patients received t-PA at 2.6 hours from symptom onset (no pretreatment angiography), also demonstrated superior $\mathrm{t}-\mathrm{PA}$ versus SK efficacy (70 vs $55 \%$, respectively, $P=.054$ ) (Figure 3). Thus, t-PA has been unequivocally demonstrated to have improved thrombolytic efficacy over SK in two randomized trials over a broad time span (Figure 4). These findings account for the selection of t-PA as the agent of choice for future large-scale 
TABLE III

\begin{tabular}{|c|c|c|}
\hline \multicolumn{3}{|c|}{ Comparison of IV Streptokinase and Tissue Plasminogen Activator } \\
\hline & SK & t.PA \\
\hline Dose & 1.5 million unit & $\begin{array}{l}\text { total } 1.0-1.5 \mathrm{mg} / \mathrm{kg}, \max 135 \mathrm{mg} \text {; first hour } \\
0.75-1.0 \mathrm{mg} / \mathrm{kg}, \max 90 \mathrm{mg}\end{array}$ \\
\hline Infarct vessel patency & $50 \%$ & $70-75 \%$ \\
\hline Time dependency & highly, $<30 \%$ patency after $4 \mathrm{hr}$ & no time dependency demonstrated \\
\hline Reocclusion & unknown & $10-15 \%$ \\
\hline Hypotension & variable, severe in $<5 \%$ patients & none \\
\hline Half-life & alpha, $18 \mathrm{~min}$; beta, $83 \mathrm{~min}$ & alpha, $4 \mathrm{~min}$; beta, $30 \mathrm{~min}$ \\
\hline Fibrinogen breakdown & severe & moderate \\
\hline Serum viscosity & $10-15 \% \downarrow$ & no significant change \\
\hline Bleeding & $\begin{array}{l}\text { common, peri-access; intracranial } \\
\text { bleeding }<0.5 \% \text { in } 20,000 \text { patients }\end{array}$ & $\begin{array}{l}\text { common, peri-access; intracranial bleeding } \\
<0.5 \% \text { in } 5000 \text { patients }\end{array}$ \\
\hline Allergic reactions & yes (fever, rash, anaphylactoid) & no \\
\hline Repeat dosing & no; $\downarrow$ efficacy, $\uparrow$ allergic reactions & yes \\
\hline Cost/dose & $\$ 200$ & $\$ 1500-2000 *$ \\
\hline
\end{tabular}

- Projected cost, not FDA approved at time of report.

trials in both the United States (TIMI) and European Cooperative Study groups.

Second, it has been argued that the dose of SK selected led to inherent bias. ${ }^{6.67}$ The standard modern dose of 1.5 million units of SK was given in both trials, and all published experience with SK does not show a relationship between dose and recanalization rate. ${ }^{28.29 .40-42.68}$ Third, there was significant (33\%) t-PA-induced fibrinogenolysis in TIMI, although nearly half that which was observed with SK. ${ }^{69}$ Despite relative sparing of coagulation proteins, t-PA did not result in a reduction of bleeding complications in TIMI, which chiefly involved periaccess sites. Although the European Cooperative Study demonstrated less bleeding episodes or transfusion requirements for t-PA than SK, ${ }^{45}$ the overall clinical trial bleeding complication rates with t-PA have not been significantly decreased compared with other lytic agents.

The reasons for this observation are multiple. A potent fibrinolytic enzyme, t-PA will lead to lysis of hemostatic plugs and noncoronary fibrin. Cardiac catheterization performed in the face of lytic therapy promotes the frequency and severity of peri-access hemorrhage. Adjunctive thromboprophylactic therapy with IV-administered heparin and antiplatelet agents further increases the likelihood of bleeding episodes.
Intracranial hemorrhage is the most serious and often catastrophic complication of fibrinolytic therapy. With IV-administered t-PA at a total dose of $\mathbf{1 5 0}$ $\mathrm{mg}$, an increased incidence of $1.6 \%$ (approximately 16 of 1000 patients) was observed. ${ }^{49.50 .72}$ At doses up to $120 \mathrm{mg}$, however, the rate has been $0.4 \%$. Intracranial bleeding appears to have a similarly low incidence with high-dose IV SK, with most reports citing less than $0.5 \%{ }^{35.37 .38}$ However, little is known about the pathophysiology of cerebrovascular bleeding induced by fibrinolytic therapy. The demographic risk factors that have thus far been associated with this event include female gender, advanced age, and long-standing or severe hypertension. ${ }^{48}$ More data and understanding will be necessary before this dreaded complication can be avoided with any of the fibrinolytic enzymes.

Besides bleeding complications, the major concern after successful thrombolysis is for sustained patency of the infarct vessel. Because serial acute and follow-up angiography has not been performed in any large-scale trial with IV SK, the true incidence of reocclusion is completely unknown. Smaller studies of IV SK have reported a wide range of reocclusion from 5 to $30 \% .{ }^{40-42.45 .46}$ The TAMI trial defined the angiographic reocclusion rate with t-PA with the use of acute coronary angiography in $\mathbf{3 8 6}$ patients and follow-up at 1 week in $95 \%$ of surviving 


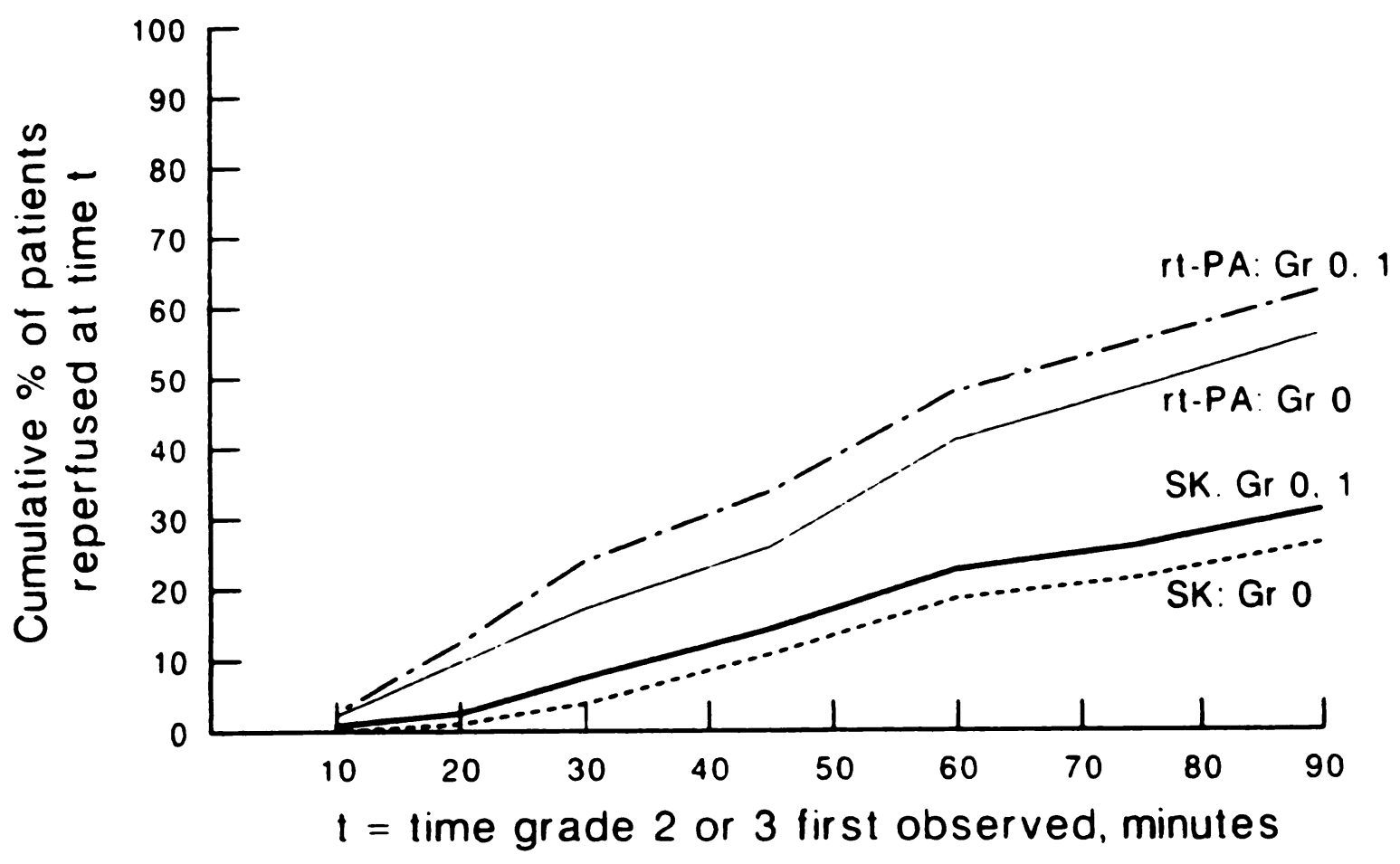

Figure 1. Coronary thrombolytic efficacy of tissue plasminogen activator (t-PA) versus streptokinase (SK). At seven serial time intervals of angiographic observation up to 90 minutes after the start of therapy, $t$-PA elicited reperfusion twice as often. (Reprinted with permission. Cheseboro et al: Circulation 1987:76:142-154.)

patients. For those patients with a significant residual stenosis who did not undergo angioplasty, the incidence of reocclusion was $13 \%$ (total t-PA dose $=150 \mathrm{mg} / 6-8 \mathrm{hr}){ }^{48}$

\section{LEFT VENTRICULAR FUNCTION AND MORTALITY}

Two recent randomized, double-blind, placebo-controlled trials of t-PA have demonstrated significant left ventricular improvement. Both the Johns Hopkins and Australian trials were just completed, but preliminary data are quite similar and support a seven- to eight-point global ejection-fraction advantage for patients receiving t-PA compared with placebo. ${ }^{70-72}$ There has not yet been a large enough randomized, prospective trial of t-PA compared with placebo or other reperfusion strategies to evaluate mortality effects.

The placebo-controlled IV SK studies that have addressed left ventricular function are those of ISAM, Western Washington and New Zealand. ${ }^{37-39}$
In ISAM, only a subset of patients were studied, but patients receiving SK had an increased global ejection fraction. Subgroup analysis of the Western Washington trial demonstrated improvement of left ventricular function in patients with anterior infarction. Despite the relatively small size of the New Zealand trial, mortality was reduced and global ejection fraction was increased in the SK-treated patients. As discussed earlier, the GISSI and ISIS-2 megatrials convincingly demonstrated the survival advantage conferred by early administration of SK compared with conventional or placebo therapy, respectively. ${ }^{35.36}$

\section{NONTHROMBOLYTIC AND RHEOLOGIC EFFECTS}

Recently, the U.S. FDA Cardiorenal Advisory Committee pointed out the disproportionate effects of IV SK on infarct vessel recanalization compared with mortality reduction. ${ }^{72}$ With SK thrombolytic efficacy of approximately $50 \%$ and acute-phase mortality 


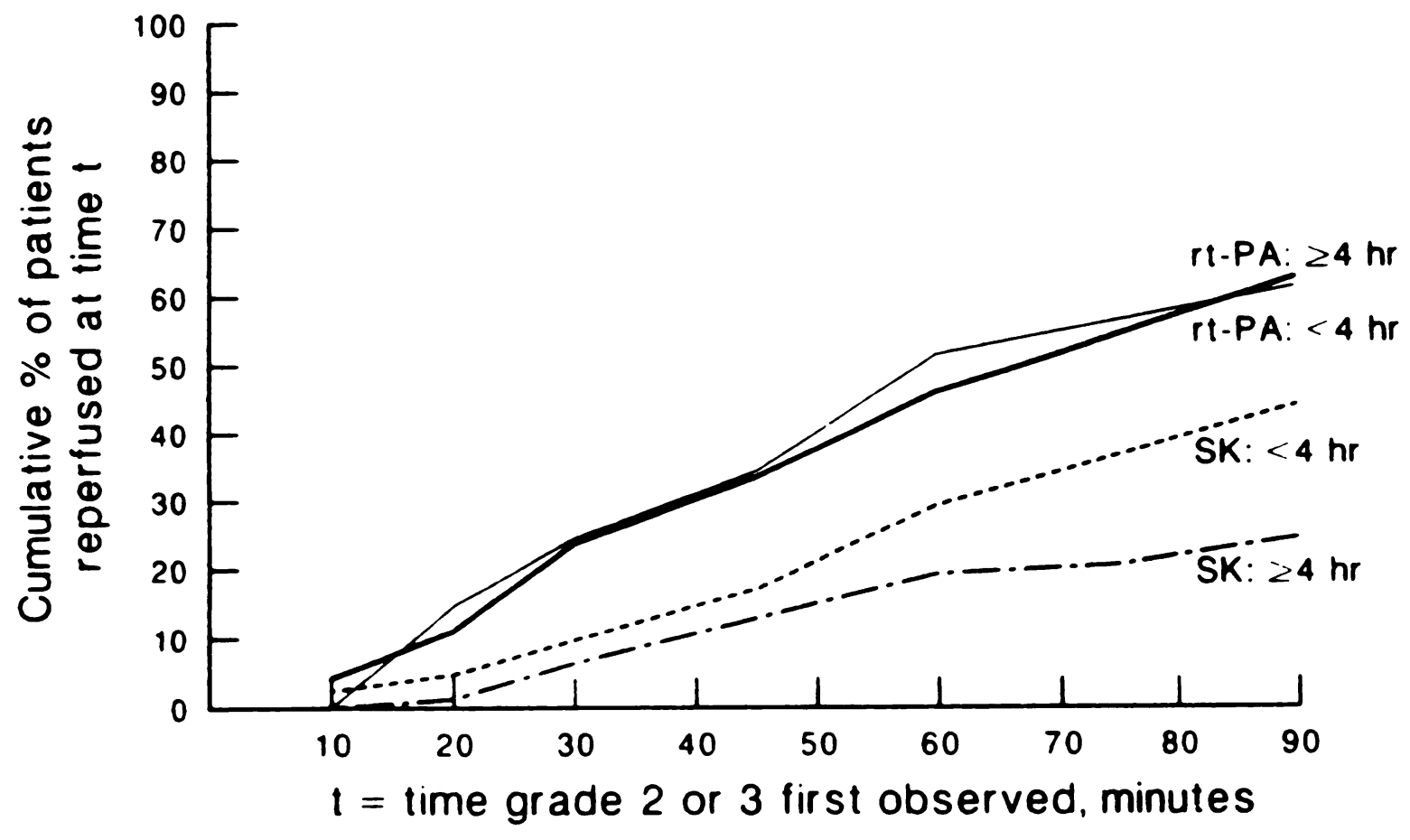

Figure 2. Difference of lytic efficacy of tissue plasminogen activator (t-PA) versus streptokinase (SK) over time. No significant difference was noted for patients treated less than or more than 4 hours from symptom onset with t-PA compared with substantially less efficacy for SK after 4 hours. (Reprinted with permission, Cheseboro et al: Circulation 1987;76:142-154.

substantial reduction of 20 to $33 \%,{ }^{15.35 .36}$ the committee members suggested that the nonthrombolytic actions of IV SK may be operational. Of the various actions of SK, blood pressure reduction, viscosity reduction, and attendant rheologic alterations, antiplatelet effects, and free oxygen radical scavenging properties are potentially beneficial in the setting of myocardial reperfusion. However, none of these properties has been adequately evaluated in prospective, clinical trials.

By report of the manufacturers, systolic blood pressure reduction with IV SK is modest, averaging only 5 to $7 \mathrm{~mm} \mathrm{Hg} .^{72}$ Clearly, this minimal diminution of blood pressure would not be associated with a significant afterload reduction. Furthermore, acutephase reduction of blood pressure in myocardial infarction has not been demonstrated to limit infarct size or decrease mortality in patients. ${ }^{73}$

Blood viscosity reduction with SK also appears to be mild, averaging 10 to $17 \%$ in two reported studies. ${ }^{74.75}$ In a small comparative study, IV SK resulted in a significant $(60 \%)$ fibrinogen reduction and only a $10 \%$ decline in blood viscosity, whereas t-PA low-

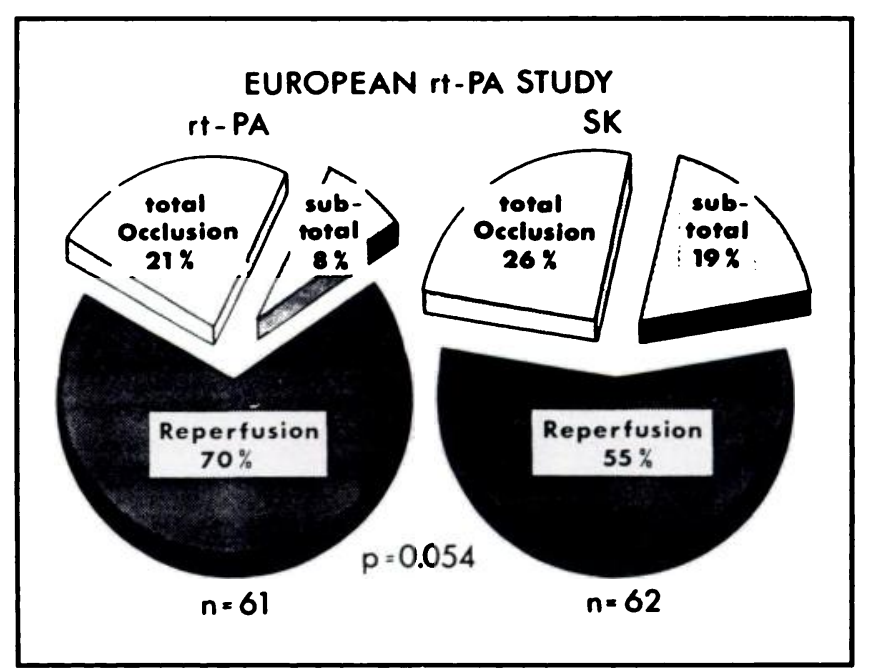

Figure 3. Difference of infarct vessel patency for tissue plasminogen activator ( $t-P A)$ versus streptokinase (SK) at 90 minutes of therapy in the randomized European Cooperative Study. Patients received SK at a median of 2.6 hours from symptom onset. (Reprinted with permission. Erbel R: The European Cooperative Trials in Acute Myocardial Infarction, in. Topol EJ (ed): Acute Coronary Intervention, New York, Alan R. Liss, 1987.) 


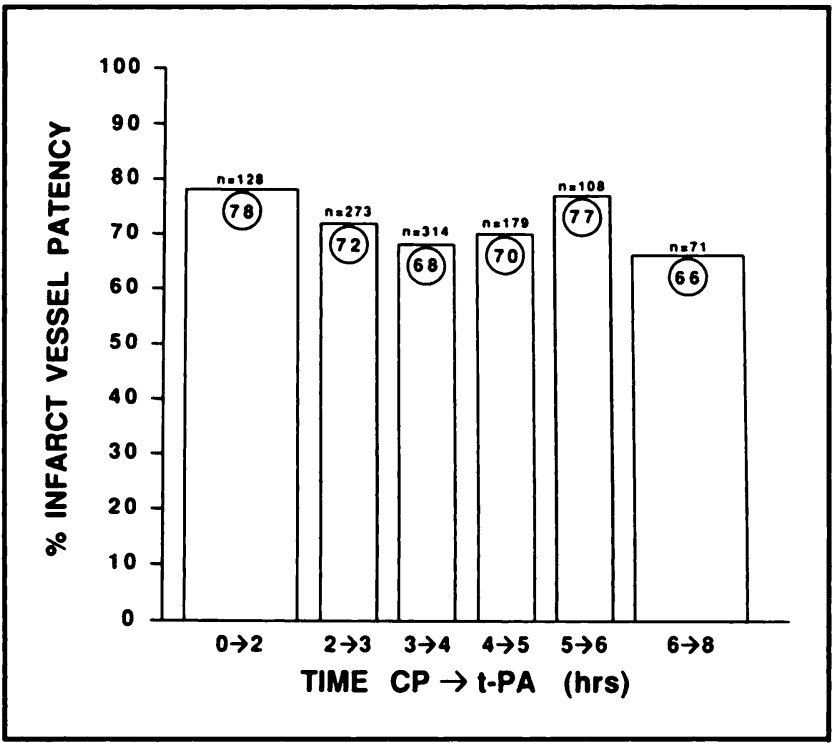

Figure 4. Consistent efficacy of tissue plasminogen activator (t-PA) over a broad time window. In a total of 1073 patients treated with IV t-PA between 20 minutes and 8 hours from symptom onset, a high level of infarct vessel patency at 90 minutes was achieved. (Data presented at FDA Cardiorenal Advisory Committee, May 29, 1987. Bethesda, MD. On file, Genentech, Inc., San Francisco, CA).

ered plasma fibrinogen by $20 \%$ and blood viscosity by $6 \%$. Red blood cell deformity was not differently affected by SK versus t-PA. ${ }^{75}$ Although reduction in viscosity is correlated with improved microcirculatory blood flow and decline in total peripheral resistance, ${ }^{74-76}$ the modest changes of blood or plasma viscosity demonstrated with SK may not be substantial enough to significantly alter clinical outcome. With scant data currently available, the viscosity and rheologic effects of fibrinolytic agents certainly require further investigation.

In an in vitro study comparing antiplatelet effects of SK urokinase, and t-PA, the most substantial inhibitory action was demonstrated for t-PA, related to platelet-fibrin binding. ${ }^{77}$ With higher levels of fibrinogen degradation products (FDP) generated by SK compared with t-PA, it is also possible that there may be more disaggregation with the former agent. ${ }^{78}$ The actual platelet function in vivo effects in humans for the various fibrinolytic agents have not been adequately differentiated to date.

The free oxygen radical scavenging property of SK has been characterized as modest, ${ }^{79}$ and the importance of this effect in myocardial reperfusion is a controversial subject. ${ }^{80.81}$ Limitation of reperfusion injury by free radical scavengers has not been demonstrated in humans although this is the focus of current clinical trials. ${ }^{82}$ With SK weak scavenging effect, it is unlikely to be of clinical significance. Recently, t-PA was suggested to have a direct myocardial function salutary effect in the experimental feline model ${ }^{83.84}$ but again no clinical data exists to confirm or rebut this observation.

In summary, there are multiple modest nonthrombolytic effects of SK, which have not been well characterized. Moreover, none of the effects have been correlated with favorable clinical outcome or improvement in ventricular function.

\section{REGULATORY ISSUES}

The FDA advisory panel decision to recommend approvability status for IV SK but not t-PA led to considerable controversy. ${ }^{72.85-89}$ As the data for the two agents were carefully scrutinized, it became apparent that the strengths and weakness for each were diametrically opposed. On the one hand, little data were available for the recanalization efficacy of IV SK but the GISSI, ISIS-2 megatrials and pooled analyses confirmed mortality reduction with this agent. ${ }^{35.36 .90}$ For t-PA, considerable evidence for high thrombolytic efficacy was presented, but lacking was a large-scale placebo-controlled trial for mortality effects. For both agents, data on improvement of left ventricular function was presented but not accepted as conclusive for the panel. Also, there was discussion regarding the different doses of $t-P A$ used in the trials (ranging from 90-150 mg total IV dose of the single-chain preparation) and a completely inaccurate account of the incidence of intracranial bleeding. ${ }^{22}$ The latter unfortunately casted doubt and concern over t-PA as a safe fibrinolytic agent.

Since this meeting, data from two placebo-controlled studies of t-PA which substantially show left ventricular functional recovery, have become available. $^{70.71}$ The availability of these data to the FDA may ultimately lead to approval of t-PA in upcoming months. However, an important issue has been raised by the panel's decision. Should a fibrinolytic agent require proven mortality or ventricular function benefit before it can be approved for use in myocardial infarction?

In 1982, when the FDA approved intracoronary SK, the answer was clearly no. No data were available to confer more than coronary thrombolytic efficacy for this reperfusion strategy. Has the field so changed in 5 years? Is coronary thrombolysis dissociated from clinical outcomes and ventricular function?

From clinical experience and the data currently available, it is clear that the major effect of all fibrinolytic agents in this setting is to lyse intraluminal thrombus and restore blood flow through the af- 
fected coronary artery. Recanalization may be of "cosmetic" benefit only when therapy is instituted too late or when myonecrosis is already complete. As long as fibrinolytic therapy is administered early and judiciously, there will be definite overall improvement in ventricular function and reduction in mortality. Denial of this principle violates the fundamental pathophysiology of acute myocardial infarction. Provided that safety of a fibrinolytic agent is confirmed, correction of the underlying occlusive clot disorder by lysis must be a desirable end point in the patient with myocardium at jeopardy. The dilemma for future regulatory boards will be in the definition of efficacy of a fibrinolytic agent. In a rapidly proliferating field of many new agents and manufacturers, this will undoubtedly lead to difficulties. If the effects of one fibrinolytic agent have correlation between thrombolytic and clinical efficacy, will this be adequate for all future enzymes? This question is currently unsettled. The efficacy threshold may be debated for many classes of drugs. For example, should all hypertensive agents document survival and stroke-avoidance benefit beyond effective lowering of blood pressure? Obviously, this is not the case. However, the analogy to fibrinolytic therapy is apparent.

\section{FUTURE OF THROMBOLYTIC THERAPY}

The last 5 years may be considered the rapid growth phase of understanding and experience with thrombolytic therapy for acute myocardial infarction. Concurrently, three new agents (t-PA, APSAC, prourokinase) have been developed for clinical use, and further biochemical modifications of these agents and combination therapies are being explored. ${ }^{91-95}$ The ultimate goals of rapid, $100 \%$ coronary thrombolytic efficacy, zero reocclusion, and absence of bleeding are highly unlikely to be achieved. There is no doubt, however, that considerable investigation will follow to approximate more closely these important objectives. In planning future clinical trials and eventual clinical release of fibrinolytic agents, regulatory agencies will have to develop rational and consistent guidelines for the definition of efficacy.

\section{REFERENCES}

1. Tillet WS, Garner RL: The fibrinolytic activity of hemolytic streptococci. J Exp Med 1983;58:485-502.

2. Tillett WS, Sherry S: The effect in patients of streptococcal fibrinolysin (streptokinase) and streptococcal desoxyribonuclease on fibrinous, purulent, and sanguinous pleural exudations. J Clin Invest 1949;28:173-190.
3. Herrick JB: Clinical features of sudden obstruction of the coronary arteries. JAMA 1912;59:2015-2020.

4. Chazov EI, Mateeva LS, Mazaev AV, et al: Intracoronary administration of fibrinolysin in acute myocardial infarction. Ter Arkh 1976;48:8-19.

5. Rentrop KP, Blanke $H$, Karsch $K R$, Kreuzer $H$ : Initial experience with transluminal recanalization of the recently occluded infarct-related coronary artery in acute myocardial infarctioncomparison with conventionally treated patients. Clin Cardiol 1979;2:92-105.

6. DeWood MA, Spores J, Notske R, et al: Prevalence of total coronary occlusion during the early hours of transmural myocardial infarction. N Engl J Med 1980;303:897-902.

7. Fletcher AP, Alkjaersig N, Smyrniotis FE, Sherry S: The treatment of patients suffering from early myocardial infarction with massive and prolonged streptokinase therapy. Trans Assoc Am Physicians 1958;71:289-296.

8. Stampfer MJ, Goldhaber SZ, Yusuf S, et al: Effect of intravenous streptokinase on acute myocardial infarction. $N$ Engl J Med 1982;307:1180-1182.

9. European Cooperative Study Group: Streptokinase in acute myocardial infarction. N Engl J Med 1979;301:797-802.

10. Van de Werf F, Nobuhara M, Collen D: Coronary thrombolysis with human single-chain urokinase-type plasminogen activator (pro-urokinase) in patients with acute myocardial infarction. Ann Intern Med 1986;104:345-348.

11. Rentrop $P$, Blanke $H$, Karsch $K R$, et al: Selective intracoronary thrombolysis in acute myocardial infarction and unstable angina pectoris. Circulation 1981;63:307-317.

12. Ganz W, Buchbinder N, Marcus $\mathrm{H}$, et al: Intracoronary thrombolysis in evolving myocardial infarction. Am Heart $J$ 1981;101:4-13.

13. Kennedy JW, Ritchie JL, Davis KB, Fritz JK: Western Washington randomized trial of intracoronary streptokinase in acute myocardial infarction. N Engl J Med 1983;309:1477-1482.

14. Simoons ML, Brand M V/D, de Zwaan C, et al: Improved survival after early thrombolysis in acute myocardial infarction. Lancet 1985; II:578-582.

15. Rentrop KP: Thrombolytic therapy in patients with acute myocardial infarction. Circulation 1985;71:627-631.

16. Khaja F. Walton JA Jr, Brymer JF, et al: Intracoronary fibrinolytic therapy in acute myocardial infarction. $N$ Engl J Med 1983;308:1305-1311.

17. Leiboff $R H, K a t z R J$, Wasserman $A G$, et al: A randomized, angiographically controlled trial of intracoronary streptokinase in acute myocardial infarction. Am J Cardiol 1984;53:404-407.

18. Raizner AE, Tortoledo FA, Verani MS, et al: Intracoronary thrombolytic therapy in acute myocardial infarction: A prospective, randomized, controlled trial. Am J Cardiol 1985;55:301-308. 19. Rentrop KP, Feit $F$, Blanke $H$, et al: Effects of intracoronary streptokinase and intracoronary nitroglycerin infusion on coronary angiographic patterns and mortality in patients with acute myocardial infarction. N Engl J Med 1984;311:1458-1463.

20. Mathey DG, Sheehan FH. Schofer J, Dodge HT: Time from onset of symptoms to thrombolytic therapy: A major determinant of myocardial salvage in patients with acute transmural infarction. J Am Coll Cardiol 1985;6:518-525.

21. Serruys PW, Simoons ML, Suryapranata $H$, et al: Preservation of global and regional left ventricular function after early thrombolysis in acute myocardial infarction. J Am Coll Cardiol 1986;7:729-742.

22. Anderson JL, Marshall HW, Bray BE, et al: A randomized trial 
of intracoronary streptokinase in the treatment of acute myocardial infarction. N Engl J Med 1983;308:1312-1353.

23. American Hospital Association Annual Survey, Washington, DC, 1986.

24. Burkey MW, Smith MR, Walsh TE, et al: Relation of effectiveness of intracoronary thrombolysis in acute myocardial infarction to systemic thrombolytic state. Am J Cardiol 1985;56:441-444.

25. Rothbard RL. Fitzpatrick PG, Francis CW, et al: Relationship of the lytic state to successful reperfusion with standard- and low-dose intracoronary streptokinase. Circulation 1985;71:562570.

26. O'Neill $W$, Timmis G, Bourdillon $P$, et al: A prospective randomized clinical trial of intracoronary streptokinase versus coronary angioplasty therapy of acute myocardial infarction. N Engl J Med 1986;314:812-828.

27. Kennedy JW, Ritchie JL, Davis KB, Fritz JK: Western Washington randomized trial of intracoronary streptokinase in acute myocardial infarction. N Engl J Med 1983;309:1477-1482.

28. Kennedy JW, Gensini GG, Timmis GC, Maynard C: Acute myocardial infarction treated with intracoronary streptokinase: $A$ report of the society for cardiac angiography. Am J Cardiol 1985;55:871-877.

29. Stadius ML, Maynard C, Fritz JK, et al: Coronary anatomy and left ventricular function in the first 12 hours of acute myocardial infarction: The Western Washington Randomized Intracoronary Streptokinase Trial. Circulation 1985;72:292-300.

30. Davies GJ, Chierchia S, Maseri A: Prevention of myocardial infarction by very early treatment with intracoronary streptokinase. N Engl J Med 1984;311:1488-1492.

31. Khaja F, Walton JA Jr, Brymer JF, et al: Intracoronary fibrinolytic therapy in acute myocardial infarction. $N$ Engl $J$ Med 1983;308:1305-1311.

32. Collen D. Topol EJ. Tiefenbrunn AJ, et al: Coronary thrombolysis with recombinant human tissue-type plasminogen activator: A prospective, randomized, placebo-controlled trial. Circulation 1984;70:1012-1017.

33. Williams DO, Borer J, Braunwald E, et al: Intravenous recombinant tissue-type plasminogen activator in patients with acute myocardial infarction: A report from the NHLBI thrombolysis in myocardial infarction trial. Circulation 1986;73:338-346.

34. Topol EJ, Morris D, Smalling R, et al: A multicenter, randomized, placebo-controlled trial of a new form of intravenous recombinant tissue-type plasminogen activator (Activase) in acute myocardial infarction. I Am Coll Cardiol 1987;9:1205-1213.

35. Gruppo Italiano per Lo Studio Della Streptochinasi Nell'Infarcto Miocardio (GISSI): Effectiveness of intravenous thrombolytic treatment in acute myocardial infarction. Lancet 1986; I:397-401.

36. ISIS Steering Committee: Intravenous streptokinase given within 0-4 hours of onset of myocardial infarction reduced mortality in ISIS-2. Lancet 1987;1:502.

37. The I.S.A.M. Study Group: A prospective trial of intravenous streptokinase in acute myocardial infarction (I.S.A.M.). N Engl J Med 1986;314:1465-1471.

38. Martin GV, Stadius ML. Davis KB, et al: The Western Washington intravenous streptokinase trial: Effects of intravenous streptokinase on vessel patency and left ventricular function. Circulation 1986;74(suppl II):Il-367.

39. White H, Brown M, Takayama M, et al: Improved left ventricular function and early survival with intravenous streptokinase: A double-blind trial. Circulation 1986;74(suppl II):II-5.

40. Spann JF, Sherry S, Carabello BA, et al: Coronary thromboly- sis by intravenous streptokinase in acute myocardial infarction: acute and follow-up studies. Am J Cardiol 1984;53:655-661.

41. Schroder R, Biamino G, Leitner E-RV, et al: Intravenous short-term infusion of streptokinase in acute myocardial infarction. Circulation 1983;67:536-548.

42. Hillis LD, Borer J, Braunwald E, et al: High dose intravenous streptokinase for acute myocardial infarction: Preliminary results of a multicenter trial. J Am Coll Cardiol 1985;6:957-962.

43. Gold HK, Leinbach RC, Garabedian HD, et al: Acute coronary reocclusion after thrombolysis with recombinant human tissuetype plasminogen activator: Prevention by a maintenance infusion. Circulation 1986;73:347-352.

44. Verstraete M, Brower RW, Collen D, et al: Double-blind randomised trial of intravenous tissue-type plasminogen activator versus placebo in acute myocardial infarction. Lancet 1985; II:965-969.

45. Verstraete M, Bory M, Collen D, et al: Randomized trial of intravenous recombinant tissue-type plasminogen activator versus intravenous streptokinase in acute myocardial infarction. Lancet 1985; I:842-847.

46. The TIMI Study Group: The thrombolysis in myocardial infarction (TIMI) trial. N Engl J Med 1985;312:932-936.

47. Garabedian HD, Gold HK, Leinbach RC, et al: Comparative properties of two clinical preparations of recombinant human tissue-type plasminogen activator in patients with acute myocardial infarction. J Am Coll Cardiol 1987;9:599-607.

48. Topol EJ, Califf RM, George BS, et al: A randomized trial of immediate versus delayed elective angioplasty after intravenous tissue plasminogen activator in acute myocardial infarction. $\mathrm{N}$ Engl J Med 1987;317:581-588.

49. TIMI report: November 1986, Dallas, Texas, George Washington University Symposium.

50. Braunwald E, Knatterud GL, Passamani ER, Robertson TL: Announcement of protocol change in thrombolysis in myocardial infarction trial. J Am Coll Cardiol 1987;9:467.

51. Williams DO: Preliminary results of the thrombolysis in myocardial infarction (TIMI) trial, in Topol EJ (ed): Acute Coronary Intervention. New York, Alan R. Liss, 1987:137-145.

52. Sobel BE. Gross RW, Robison AK: Thrombolysis, clot selectivity, and kinetics. Circulation 1984;70:160-164.

53. Collen D. Bounameaux H, de Cock F, et al: Analysis of coagulation and fibrinolysis during intravenous infusion of recombinant human tissue-type plasminogen activator in patients with acute myocardial infarction. Circulation 1986;73:511-517.

54. Topol EJ, Bell WR. Weisfeldt ML: Coronary thrombolysis with recombinant tissue-type plasminogen activator: Hematologic and pharmacologic study. Ann Intern Med 1985;103:837-843.

55. Collen D, Topol EJ: Tissue-type plasminogen activator, in Topol EJ (ed): Acute Coronary Intervention New York, Alan R. Liss, 1987:33-45.

56. Mathey DG, Schofer J, Sheehan FH, et al: Intravenous urokinase in acute myocardial infarction. Am J Cardiol 1985;55:878882.

57. Anderson IL, Rothbard RL, Hackworthy RA, et al: Randomized reperfusion trial of intravenous anisoylated plasminogen streptokinase activator complex (APSAC) versus intracoronary streptokinase in acute myocardial infarction: Interim report. Circulation 1986;74:II-6.

58. Walker ID, Davidson JF, Rae AP, et al: Acylated streptokinase-plasminogen complex in patients with acute myocardial infarction. Thromb Haemost 1984;51:204-206.

59. Kasper W, Erbe R, Meinertz T, et al: Intracoronary thrombolysis with an acylated streptokinase-plasminogen activator (BRL 
26921) in patients with acute myocardial infarction. JACC 1984:4:357-363.

60. Hillis WS, Horning RS, Dunn FG: Coronary reperfusion following single dose intravenous BRL 26921 [abstract]. Circulation 1984;70(suppl II):II-28.

61. Marder VJ, Rothbard RL, Fitzpatrick PG, et al: Dose response study of intravenous acylated streptokinase: Plasmin complex (BRL26921) in coronary artery thrombosis. Circulation 1984;70(suppl II):II-29.

62. Been M, de Bono DP, Muir AL, et al: Clinical effects and kinetic properties of intravenous APSAC-anisoylated plasminogen-streptokinase activator complex (BRL 26921) in acute myocardial infarction. Int J Cardiol 1986;11:53-61.

63. Marder VI, Rothbard RL. Fitzpatrick PG, Francis CW: Rapid lysis of coronary artery thrombi with anisoylated plasminogen: Streptokinase activator complex. Ann Intern Med 1986;104:304310.

64. Van de Werf F, Nobuhara M, Collen D: Coronary thrombolysis with human single-chain urokinase-type plasminogen activator (pro-urokinase) in patients with acute myocardial infarction. Ann Intern Med 1986;104:345-348.

65. Van de Werf F, Vanhaecke J, de Geest H, et al: Coronary thrombolysis with recombinant single-chain urokinase-type plasminogen activator in patients with acute myocardial infarction. Circulation 1986;74:1066-1070.

66. Shery S: Tissue plasminogen activator (t-PA): Will it fulfill its promise? N Engl J Med 1985;313:1014-1017.

67. Sherry S: Recombinant tissue plasminogen activator (rt-PA): Is it the thrombolytic agent of choice for an evolving acute myocardial infarction? Am J Cardiol 1987;59:984-989.

68. Chesebro JH, Knatterud G, Roberts R, et al: Thrombolysis in Myocardial Infarction (TIMI) Trial, Phase I: A comparison between intravenous tissue plasminogen activator and intravenous streptokinase. Circulation 1987;76:142-154.

69. Rao AK: Thrombolysis in myocardial infarction trial (phase I): effect of intravenous tissue plasminogen activator and streptokinase on plasma fibrinogen and the fibrinolytic system. Circulation 1985;72:III-416.

70. Guerci AD, Gerstenblith G, Brinker JA, et al: A randomized, placebo-controlled, double-blinded trial of intravenous tissue plasminogen activator with subsequent randomization to elective coronary angioplasty for acute myocardial infarction. $N$ Engl I Med 1987;(submitted).

71. O'Rourke M. Baron D, Keogh A, et al: Randomized placebo controlled double blind trial of intravenous recombinant tissue plasminogen activator initiated within 2.5 hours of symptom onset in acute coronary occlusion. Lancet 1987; (submitted)

72. Minutes of FDA Cardiorenal Advisory Committee Meeting. Bethesda, MD, May 29, 1987.

73. Rude RE, Muller JE, Braunwald E: Efforts to limit the size of myocardial infarcts. Ann Intern Med 1981;95:736-761.

74. Arntz R, Heitz J, Schafer H, Schroder R: Hemorrheology in acute myocardial infarction: Effects of high dose intravenous streptokinase. Circulation 1985;72:III-417.

75. Jan K, Reinhart W, Chien S, et al: Altered rheological properties of blood following administration of tissue plasminogen acti- vator and streptokinase in patients with acute myocardial infarction. Circulation 1985;72:IIl-417.

76. Dormandy J, Ernst E, Matrai A, Flute PT: Hemorrheologic changes following acute myocardial infarction. Am Heart J 1982;104:1364-1367.

77. Vaughn DE, Loscalzo J: Dissaggregation of platelets: A comparison of tissue plasminogen activator, streptokinase and urokinase. Circulation 1986;74(suppl II):II-95.

78. Sobel BE, Gross RW, Robison AK: Thrombolysis, clot selectivity, and kinetics. Circulation 1984;70:160-164.

79. Fung AYM, Rabkin SW: Beneficial effects of streptokinase on left ventricular function after myocardial reoxygenation and reperfusion following global ischemia in the isolated rabbit heart. J Cardiovasc Pharmacol 1984;6:429-435.

80. Werns SW, Shea MJ, Lucchesi BR: Free radicals and myocardial injury: Pharmacologic implications. Circulation 1986;74:1-5. 81. Uraizee A, Reimer KA, Murry CE, Jennings RB: Failure of superoxide dismutase to limit size of myocardial infarction after 40 minutes of ischemia and 4 days of reperfusion in dogs. Circulation 1987;75:1237-1248.

82. Werns ST: Strategies to limit reperfusion injury, in Topol EJ (ed): Acute Coronary Intervention. New York, Alan R. Liss, 1987:263-283.

83. Darius $H$, Yanagisawa A, Brezinski ME, et al: Beneficial effects of tissue-type plasminogen activator in acute myocardial ischemia in cats. J Am Coll Cardiol 1986;8:125-131.

84. Jaffe AS: New mechanism of action for tissue-type plasminogen activator? J Am Coll Cardiol 1986;8:132-133.

85. The Wall Street Journal, Editorial: Human sacrifice. June 2 , 1987.

86. The Wall Street Journal, Editorial: The Flat Earth Committee. July $13,1987$.

87. The Wall Street Journal, Editorial: The decision against a heart drug. July 13, 1987.

88. Sun M: FDA puts new heart drug on hold. Science 1987;237:16-18.

89. Schlender BR, Waldholz M: Drug on trial-Genentech's missteps and FDA policy shift led to TPA setback. The Wall Street Journal, June 16, 1987.

90. Koshland DE: TPA and PDQ. Science 1987;237:341.

91. Yusuf $S$, Collins $R$, Peto $R$, et al: Intravenous and intracoronary fibrinolytic therapy in acute myocardial infarction: Overview of results on mortality, reinfarction and side-effects from 33 randomized controlled trials. Eur Heart J 1985;6:556-585.

92. Collen D. Stassen J, Stump DC, Verstraete M: Synergism of thrombolytic agents in vivo. Circulation 1986;74:838-842.

93. Collen D, Stump DC, Van de Werf F: Coronary thrombolysis in patients with acute myocardial infarction by intravenous infusion of synergic thrombolytic agents. Am Heart J 1986;58:10831084.

94. Ehrlich HJ, Bang NU, Mattler LE, et al: Biologic properties of a tissue plasminogen activator mutant. Circulation 1986;74(suppl II):II-246.

95. Bode C. Runge MS, Newell JB, et al: Thrombolysis by a fibrin-specific antibody Fab'-urokinase conjugate. J Mol Cell Cardiol 1987;19:335-341. 